\title{
El Perú Sur
}

(DE “RAdiografia de la literatura peruaNA")

CUILlERMO Mercado fué el poeta sureño de perfil lírico más $G$ elocuente en la primera promoción regionalista. Desde la geografía luminosa y cordial de su Arequipa, alzó la voz ancha, gozosa, optimista de Tremos. Luego se identifica al cholo arequipeño para darnos la prosa del Donato. El paisaje y su hombre unirian más tarde su realidad emotiva para expresarse por las estampas plásticas de Un chullo de poemas.

Alejandro Peralta luce otra expresión y la rubrica sobre un mapa definido: la meseta. Su poesía nace estremecida por una pesadumbre desolada - función del paisaje-, pero grávida de vitalidad $y$ trascendencia. Es un vasto río poético sobre el que espejea, como un azogue trágico, el alma en protesta de los gentíos sojuzgados. Es en 1934 cuando su verso se define, pero sin alcanzar en su expresión las tonalidades revolucionarias con que ptieda justificarse este juicio de Tauro: "Peralta se transforma de turista de su propio escenario en intérprete de aspiraciones humanas y en campeón de los desheredados." Simplemente se le apagan las pupilas contemplativas y, avanzando a la comprensión del hombre, pone en sus labios las palabras que bordean la protesta:

ya entiendo que no sólo los indios mueren a miles, sino también los obreros y campesinos.

Con el puro aliento nativo de Altipampa se alinea en 1933 la voz de Emilio Vásquez. Sólo en 1940 y en Kollasuyo se decide a ingresar, aunque con paso cauteloso, a la oscura tragedia de su gente. 
Fruto de un impulso social casi maduro es, en cambio, la poesía de alma levantada y combativa que saca a luz Manuel Gallegos Sanz (El flechero satírico, 1932). Saliendo del compás romántico de Rumores de Titicaca, Alberto Cuentas evoluciona a una mejor captación del paisaje (Desde la cumbre, 1934). Otras voces líricas se juntan al coro regionalista con expresión de menor calibre: entre los desaparecidos figura Alberto Guill, cuyo ágil espíritu, de grandes intuiciones poéticas, tornó a la región en los últimos años de su vida. La muerte impidió la consumación de una obra que maduraba bajo los soles mestizos de Arequipa, de la que son muestras elocuentes su Cancionero y el inconcluso Arequepay.

La más reciente promoción presenta la novedad lírica bien vertebrada de Luis Angel Aragón y el surgimiento de Luis Nieto. Fuerte y labrada a tajos como todo fruto serrano, la poesía de ambos; pero el verso de Nieto, contenido por la rienda formal, no alcanza la dinámica lírica y la elemental frescura de los poemas de Aragón.

Repetiré por necesarias las afirmaciones sobre la fisonomía lírica del sur-pertiano hechas en el prólogo de mi libro El hondero de la laja encendida (Lima, 1939). Se advierten de inmediato estas características en los poetas del sur: una modulación casi primitiva por la fresca sugerencia; giros y metáforas desusados para el mecanismo occidental del castellano; el amago constante pero certero de voces quechtas y aymaras en el verso. Esto último está lejos de ser modalidad negativa y menos afán de descastellanizarnos, tal cual la cándida expresión de los escribidores castizos. La razón es sencilla y lógica: nadie ignora que en el sur alternan mano a mano aymara, quechua y castellano; no es extraño que el quechua, idioma más dulce y flexible, reemplace al castellano en todos los menesteres de la intimidad y se haga presente en las expresiones más significativas de la efusión lírica. Antero Peralta explica bien este fenómeno cuando dice: "Así como el poligloto alemán acomoda inconscientemente los diferentes idiomas que habla a la sintaxis de la lengua germana, de la misma manera nuestros escritores y poetas acomodan el castellano a los resortes mecánicos de la estructura gramatical y lógica del quechua o del aymara, y como hay palabras, giros y figuras literarias en las lenguas nativas sin equivalente en castellano, no hay más remedio que consignarlas."

Si la poesía sureña presenta un nativismo vigoroso que oscila entre un magnífico impresionismo paisajista y un débil expresionis- 
mo social, la prosa tiene expresiones sociales más definidas y la asiste un espíritu consecuente con la altiva línea tradicional de su región.

Escenario no tanto de los debates, sino de los impulsos y decisiones revolucionarias de casi toda la historia peruana, el sur tiene un clima espiritual beligerante. La más grande rebelión reivindicadora aborigen estalló en Cuzco, con José Gabriel Condorcanqui. Allí salió a luz la patriótica conspiración de Aguilar y Ubalde, como la soberbia insurgencia de Pumacahua liquidada en Humachiri. De Arequipa nació el primer grito de protesta contra Pezet, generando el gallardo movimiento continental contra el amago imperialista español. Los trajines montoneros, el fragor de los combates, la inquietud de motines y conjuras; las descargas de los fusilamientos y la fanfarria de las dianas; la requisitoria vibrante de los manifiestos, el entusiasmo resuelto de las barricadas, la voluntariosa escuela de espadas y fusiles, le labran al sur un alma de proclama y una fe indoblegable en la elocuencia de la acción. Nadie ha resumido mejor que L. A. Sánchez la fisonomía sur-peruana: "El sur es polémico y belicoso. Topográficamente tierra de volcanes. Históricamente, región guerrera, ya sea en tiempos del Imperio, ya cuando la revolución de la independencia, ya cuando la República. Ideológicamente, extremista. Formalmente, polémica."

Esta beligerancia espiritual y realizadora del sur adquiere otro rumbo y mejor contenido en los tiempos actuales. Nueva actitud de su beligerancia tiene dignas cabeceras en la rebeldía social de José Gabriel Condorcanqui, y se organiza bajo los mandatos reivindicadores de la realidad presente. $Y$ es que el sur es la región donde "se perciben más intactos los raigones de la feudalidad". Las antiguas generaciones no entendieron o no quisieron entender que la transformación del Perú no puede basarse, entonces como ahora, sino en la cancelación de la servidumbre, el gamonalismo y el latifundio, expresiones comunes del régimen económico feudal que dejó España. La polémica de federalistas y centralistas - con la bandera federalista generalmente en manos del sur- simplemente se redujo a la lucha en pro o en contra de una mera forma de gobierno. No llegó a la medula del problema ni dió con. la clave de su solución: la transformación de las bases económicas del Estado. Si bien es cierto que el neoliberalismo de Urquieta y el radicalismo de Gómez de la Torre mantuvieron y exaltaron la inquietud renovadora y polémica, admitamos también que no llegaron al enjuiciamiento del drama que tenían 
a la vista. Correspondería a los indigenistas intuir o acercarse a la verdadera solución. Salvando la etapa del indigenismo romántico, los indigenistas plantearon la redención del indio por la solución del problema de la tierra, liquidando para siempre la boga de aquellos remedios pregonados por más de un siglo para escamotear la solución real del problema (legislación tutelar, cruce de razas, acción eclesiástica, el uso del alfabeto).

Insistamos en que esta primera actitud indigenista estuvo muy teñida de romanticismo verbal, egoísmo regionalista y andinismo pugnaz y excluyente. En la segunda actitud -a la que sólo avanza el grupo más resuelto, sincero y comprensivo--, el romanticismo verbal se trocó en la actitud realista para organizar el alegato de la redención económica; una conciencia serrana nacional superó al egoísmo regional parcelado, y el andinismo avanzó a la comprensión del drama social y humano de la Costa, región enfendada al latifundio, engendro de la economía colonial, como su hermano el gamonalismo serrano. Bajo el comando de la nueva generación, la Sierra actual - quitando a su inquietud reivindicadora la mera etiqueta indigenista - plantea la abolición nacional del régimen económico injusto y anacrónico, para la consumación de la cabal unidad peruana sobre las bases perdurables de la justicia social.

Colaborando en la formación y evolución del movimiento indigenista —con diferente actitud y desde diversos ángulos-, actuaron José Antonio Encinas, Uriel García, Atilio Sivirichi, Emilia Romero, J. M. Polar, F. Gómez de la Torre, Guillermo Guevara, Gamaliel Churata, J. Angel Escalante, Luis E. Valcárcel, Antero Peralta, Guillermo Mercado, L. Velasco Aragón, E. More, M. A. Urquieta, Frisancho, J. Z. Portugal, Víctor Guevara, Luis Bustamante.

El sur conoce bien a este grupo. Sabe por ello quiénes mantienen hasta hoy sus posiciones, quiénes se enquistaron en la primera actitud y quiénes han dado pasos atrás, acorralados por las conveniencias políticas o renegando tristemente de su conducta anterior.

Entre los nuevos y más definidos sostenedores del regionalismo se mencionan los nombres de Rómulo Meneses -escritor desterrado-, Alfredo Yepes, Jorge Bouroncle, Julio Luna Pacheco, Emilio Traverso, N. Rivera Cáceres, Lisandro Luna y la promoción de valores que va perfilándose gallardamente en los centros universitarios.

Resta decir que en el cuento se ha revelado un fuerte y original temperamento: Olivares del Huerto (Cuentos Lonccos). El ensayo 
y la novela tienen en Antero Peralta un cultor responsable y vigoroso que comparte con José María Arguedas la dirección renovadora de la novela regional sureña.

Completando el mensaje cabal del arte, no podian faltar las expresiones de la pintura y la música. Exhibición de una belleza cálida y dramática que conjuga la emoción violenta del paisaje y sus gentes, es la que organizan en su creación constante los pinceles de Olazo y Pantigoso.

Rescatando para la posteridad el bello recado de las melodías aborígenes trabajan las guitarras de Vivanco, los charangos de Núñez y Negrón, el alma de Gilberto Aragón y el primer violín de la sinfónica vernácula: Ulises Lanao. El vals cholo, mestizo como el yaravi enraizado al romance insigne de Melgar, sigue floreciendo con el impulso diestro que han sabido imprimirle las manos hábiles de Benigno Ballón Farfán.

Abraham Arias Larreta 
